\title{
EFL Learners' Perception toward an Outdoor Learning Program
}

\author{
Candra Hadi Asmara (Corresponding author) \\ Faculty of Education and Teacher Training, University of Muhammadiyah Gresik, Indonesia \\ E-mail: cha_ragil77@yahoo.com \\ Khoirul Anwar \\ Faculty of Education and Teacher Training, University of Muhammadiyah Gresik, Indonesia \\ E-mail: anwarkhoirul41@gmail.com \\ Ribeh Najib Muhammad \\ Faculty of Education and Teacher Training, University of Muhammadiyah Gresik, Indonesia \\ E-mail: ribeh.nm@gmail.com
}

Received: 10-02- 2016

doi:10.7575/aiac.ijels.v.4n.2p.74
Accepted: 29-04-2016

URL: http://dx.doi.org/10.7575/aiac.ijels.v.4n.2p.74

Published: 30-04-2016

\begin{abstract}
The aim of this study was to investigate EFL learners' perception of an outdoor learning program, called English Scout Organization which was developed to strengthen their students' interests in learning English at secondary school. For this purpose, the 20 secondary school students in YPI Darussalam Cerme Gresik, Indonesia, were given questionnaires related to the intervention program. The program was designed for sixteen sessions with the activities including simple jigsaw, drilling, and group work activities which were scheduled in a weekly program. The students were tested in the eighth session (One Day Big English Competition) and in the sixteenth session (English Camp). These two steps of evaluations were employed to check the effectiveness of the implementation and the process of all the scheduled programs and to measure students' participation levels. Based on the analysis of the data collected, it was found that they enjoyed the English Scout Program both individually and in groups. They indicated that they enjoyed non-formal activities especially playing games, competitions, and adventures and their interests towards English learning were also strengthened during the implementation of the program.
\end{abstract}

Keywords: Outdoor Learning Program, English Scout Program, Students’ Interest

\section{Introduction}

These days more and more demands to master a foreign language, especially English, are increasing. It is proven by the expansion of English tutoring services in Gresik, which offer a variety of innovative learning activities as the additional program for the learning process at school. Most of the owners of these English tutoring services see the opportunities from the lack of effective English teaching and learning process conducted in formal situations at school. They try to approach informal learning with the aim of increasing love and motivation of the students in learning English. However, in practice the tutoring services can only accommodate a small number of students because of their limited quota and expensive admission fee.

That problem also occurs in the secondary school YPI Darussalam Cerme. The students' desire to learn English cannot be maximized by simply following the process of learning during school hours. In order to prepare excellent individuals by mastering English in secondary school YPI Darussalam Cerme, all students must be familiar with English since it is the international language which is used by people to communicate with others from different countries. Furthermore, English is one of the important school subjects, especially in middle and high school levels, because the English language is one of the subjects in the National Exam. As the principle of 'reciprocal duty' due to parents' obligation of giving their children the best education takes effect, the interest of studying English becomes higher especially when English is associated with the children's main course for securing their future career (You and Dornyei, 2014).

In an effort to realize the vision of excellent individuals by mastering English, secondary school YPI Darussalam Cerme has problems in conceptualizing and selecting staff who can teach English with fun and engaging activities in nonformal situations outside school hours. They want an English learning process that can make students become attached in learning this international language without interfering school hours.

One possible solution is to establish English Scout Organization (ESO) which is held every Sunday at the school. ESO is an organization in which students learn English with fun and relaxed atmosphere. It is always conducted as an outdoor class activity. The terms 'outdoor learning' and 'outdoor education' are interchangeably used. Regarding the 
purpose of this research and development program, we would prefer to use the word 'outdoor learning' adhering to Beames, Atencio, and Ross (2011), who consider outdoor learning activities involve many kinds of teaching and learning activities that take place outside the classroom. In addition, outdoor learning is commonly associated with learning sustainability; meaning that, learning is developed from the students' ability in managing their futures in a sustainable way. Porritt, Hopkins, Birney and Reed (2009) argue that education is the main way to make a significant contribution for a sustainable future for every child.

So, related to the purpose of this research, we define outdoor activities as any kinds of activities conducted outside of the class and designed as a medium for learning English. Basically children like doing something in a fun atmosphere, outdoor than indoor. There will be risks if the activities are not designed in a good way and of course with the proper handling from the instructors. There is growing concern that for urgent reasons from educational trends to fears over health and safety of the children, they are missing out on the vital learning that can only be offered through outdoor activities. The risks that would be faced by the children when they learn through outdoor activities will stimulate their creativity in solving problems. It is strengthened with the expert explanation, in No Fear, by Gill (2009), who writes about the role of risks in childhood, arguing that certain types of risk that are faced by children will give them an ability in acquiring practical skills, and in understanding how to manage the consequence of the risk safely and keep themselves secure from the subsequent damage. He also states that children have a natural instinct for managing risks that should be directed toward educational and free play opportunities, while avoiding exposure to greater, unmanaged risks. Furthermore, he explains that outdoor activities always involve some risk, but the risks are greatly outweighed by the health and development benefits. Gill (2009) argues that students shape their characters as well as their personalities by facing risks in their activities since it can improve their self-reliance, resilience and adventurousness. These can be incorporated by having meaningful outdoor activities or games every once in a while. Thus, the activities support one of the elements in cooperative learning since students would benefit from the ability to socialize and share knowledge within a group or team (Arifani, 2016).

Outdoor learning activities have beneficial impact which is not only good for children but also for adults. Dillion (2005) says that the advantages of the outdoor learning activities are clearly not detained to the students' liberty. Teachers noted the improvement of their relationships with students, personal development in their own teaching and improvements in the curriculum. If outdoor learning is to be used successfully as an applied method in schools, there has to be a positive approach to use the outdoors from the start of a child's education. Moreover, the adult outdoors' manners and activities have significant effects on what happens and on children's learning. Therefore, it is imperative that children have the support of helpful and engaged adults who have a great passion about outdoor activities and recognize the importance of outdoor learning (DCSF, 2007).

It may be impossible to differentiate the learning process that actually happens in school from learning that takes place at home. In search of understanding this diversity, it is obliging to draw on an explanation of differing concepts of 'environmental learning' proposed by Scott and Gough (2003). There are nine categories of curiosity which catch, although in a rather uncertain way, a range of dissimilar focuses and objectives of those who adopt and encourage environmental learning (Scott and Gough, 2003). Applying this model to the outdoor context, outdoor education can be described as an idea and put into practice with a range of diverse locations, focuses and promising learning outcomes.

Table 1. Potential focus for outdoor education against potential outcomes by Scott and Gough (2003)

\begin{tabular}{|c|c|}
\hline Focus of outdoor education can include & Intended outcomes such experiences can include \\
\hline - learning on the subject of nature, for instance, in an ecological or & - knowledge, for example, geographical processes, ecology or the \\
\hline $\begin{array}{l}\text { - learning concerning to civilization, for example, in community-based } \\
\text { gardening initiatives or conservation projects }\end{array}$ & $\begin{array}{l}\text { - attitudes towards, for example, intensive stock rearing, access to } \\
\text { the countryside or fair trade }\end{array}$ \\
\hline $\begin{array}{l}\text { - learning in relation to nature-society interactions, for example, in } \\
\text { visits to outdoor nature centre or areas of outstanding natural setting }\end{array}$ & $\begin{array}{l}\text { - Values about, for example, the value of the environment, one's } \\
\text { relationship to it, or biodiversity loss }\end{array}$ \\
\hline $\begin{array}{l}\text { - learning on character, for example, in personal fulfillment through } \\
\text { challenging adventure education }\end{array}$ & $\begin{array}{l}\text { - } \quad \text { personal development, for example, self-confidence, knowing } \\
\text { fact from value, increasing personal effectiveness }\end{array}$ \\
\hline $\begin{array}{l}\text { - learning on the subject of cooperation with others, for example, in } \\
\text { small-group fieldwork or residential experience }\end{array}$ & $\begin{array}{l}\text { r example, pro-environment actions } \\
\text { nitment }\end{array}$ \\
\hline $\begin{array}{l}\text { - learning new skills, for example, through fieldwork or practical } \\
\text { activities in school grounds }\end{array}$ & $\begin{array}{l}\text { - behaviors, for example, identification of species with map- } \\
\text { reading }\end{array}$ \\
\hline $\begin{array}{l}\text { - learning about practical conservation, for example, through focused } \\
\text { activities in the countryside or on city farms }\end{array}$ & $\begin{array}{l}\text { - } \quad \text { skills, for example, in clearing or removing invasive alien } \\
\text { species }\end{array}$ \\
\hline $\begin{array}{l}\text { - learning with reference to influencing civilization, for example, by } \\
\text { campaigning on controversial issues }\end{array}$ & $\begin{array}{l}\text { - } \text { social development, for example, working with others, or } \\
\text { reducing racism }\end{array}$ \\
\hline $\begin{array}{l}\text { - learning research skills, for example, through action research on } \\
\text { field }\end{array}$ & $\begin{array}{l}\text { - Improved competence efficiently to get an enquiry on one's own } \\
\text { or other's work with children }\end{array}$ \\
\hline
\end{tabular}


In this program students learn in a variety of activities (games, singing, materials and others) that facilitate their vocabulary development and communication in English. It goes in line with what Pound (2005) has explained in How Children Learn. In the $16^{\text {th }}$ century Comenius (Komensky) talked of developing schooling through play, and learning through the senses. He developed a branch of philosophy which is well known as pan sophism which means 'all knowledge', and gives equal weight to knowledge, spirituality and emotional well-being in the pursuit of learning and development. In other words, learning through play will increase students' motivation while learning in a very enjoyable situation. If the student has had a lot of vocabulary and can communicate well in English, then students will find it easier to master all English language skills, namely writing, reading, listening and speaking. Thus, with the ESO the school can also help students improve their skills in English language lessons at school. Because by following the ESO activities students will gain knowledge about the English language without feeling pressured. Moreover, students will gain a new understanding of how learning English can be fun too; therefore, not only the English proficiency of students is expected to increase but also their motivation to deepen and help them learn English at school more effectively. This is highly influenced by the students' motivation since doing learning activities both inside and outside classroom is one of the key factors of their achievement in learning English (Dornyei, 2005).

The objective of this study is to measure the students' perception towards the effectiveness of English Scout Organization (ESO) as an outdoor learning program which was developed to accommodate the students' needs in order to motivate them to be more interested to learn English.

\section{Method}

This is an evaluation study of the implementation of an outdoor class at the secondary school of YPI Darussalam Cerme, Gresik, Indonesia. Evaluation study is used as a tool and procedure to analyze two things. The first function is to analyze and measure a program in order to gather the necessary information regarding the process as well as the result. The second function is to analyze and report the success rate of the program (Wollman, 2003). An evaluation study can be goals-based to emphasize on the measurement of the result from a certain program or intervention towards the subjects of the study (Patton, 2002).

The program was developed by following common steps, including needs analysis, design and model development (intervention), and revision (Anwar, 2000; McGriff, 2000; Sugiyono, 2011; Anwar \& Husniah, 2016; Arifani, 2016). These several phases are necessary to be implemented in order to get the maximum interest of learning English outside the class.

After conducting needs analysis, English Scout Program was finally designed and developed into sixteen meetings, each of which lasted two hours. During the implementation, two kinds of assessment breaks were employed, the first one was a program called One Day Big English (one-day evaluation of students' achievement after eight meetings) and the second one was English Camp (a camping program which was oriented to evaluate overall performances of students after completing sixteen meetings).

\subsection{Instruments and Participants}

To check the acceptability of the implementation, a questionnaire with a four-point scale was given to the students. Before it was distributed, the questionnaire was piloted on thirteen students (not selected as the sample of this study but still in the same batch) and then analyzed using SPSS 17.0 to see its reliability index. The internal reliability of the items was 0.97 , which was greater than 0.70 , the acceptable cut-off point of reliability (Zulganef, 2006). Appendix A shows the detailed results of internal reliability. After the questionnaire had been piloted, it was distributed to the subjects of the study, the 20 students (out of 45 total students), who actively joined the program throughout the 16 sessions.

\subsection{Data Collection Procedures and Analysis}

The questionnaire consists of twelve items related to students' response in terms of learning objectives, materials, activities, authenticity, evaluation, and motivation. After the data elicited by the questionnaire were collected from 20 participants of English Scout Program (outdoor class activities), they were analyzed quantitatively using descriptive statistical methods, including frequency and percentage. At this point, the global interest of the student after the development of the program (as the intervention) was evaluated and conclusions were made.

\section{Results and Discussions}

The evaluation study was initially done by Research and Development which has at least three steps; needs assessment, development of the program and evaluation. The needs analysis was done by identifying learning necessities of the students and teachers to establish an appropriate program especially on how to create an extra-curricular program which would help students enhance the atmosphere to learn English at the junior high level.

The needs assessment was done by interviewing teachers especially on how the school already developed the extracurricular activities, what facilities there were and who were in charge of the program. This needs assessment was initially done by interviewing three English teachers at the secondary school YPI Darussalam Cerme Gresik. Up until then, extra-curricular activities had not been established yet because there was no appropriate format to do the activities. The results of the needs analysis are summarized in Appendix B. 
From the results of the needs analysis, an extra-curricular program was developed, which was named as English Scout Program. The program was developed to motivate students to learn English in the extra-curricular format. Each session took 2 hours. The venue was the classrooms and school yards that optimally would provide indoor and outdoor activities. Each session had the following procedures: Opening, Playing Games, Interactive activities related to fun and interesting materials, Review, and Closing. The materials needed were banners, flags, tents, and four sticks of $2 \mathrm{~m}$ long. The activities were both indoor and outdoor. A combination of both types of activities was expected to encourage students' learning atmosphere better.

There were 16 sessions presenting various materials that were commonly required by the students to communicate inside and outside the classroom context. The detailed content of the materials can be viewed in Appendix C. As the appendix also shows, the activities which are used in English Scout Program go in line with the differing concepts of 'environmental learning' proposed by Scott and Gough (2003). Not all of the focuses that are proposed by Scott and Gough were applied in the activities of Scout English Program but six topics were found to be particularly successful:

1. Learning about the nature, as we could see, helped the students develop the vocabulary related to the names of vegetables and fruits.

2. Learning concerning civilization encouraged the students to work together to solve problems through discussions.

3. Learning about social interactions that was done by prompting the students to discuss in an interactive jigsaw.

4. Learning about relations and characters by playing a game called "family tree".

5. Learning about the subject of cooperation with others, which combined several activities such as discussion in a jigsaw model (either simple or interactive), and role play in the game of "family tree".

6. Learning new skill by playing games related to occupations. Because they were still students, they did not work yet, so they needed to know what kind of skills should be mastered in a certain job.

Of the 16 sessions, there were two non-regular activities which were done during the break periods. These break periods were in fact to evaluate the activities during the implementation of this program. The first break period was after the $8^{\text {th }}$ session, when the students were invited to participate in the One Day Big English program. This was a non-regular program which was implemented in the middle of the program from 07.00 a.m. until 04.00 p.m. The goal of this activity was to check and evaluate all the eight previous activities, and more specifically:

a. to evaluate individual and group participation;

b. to provide cognitive and affective reinforcement; and

c. to evaluate the program itself.

The second non-regular program was called the English Camp which was implemented at the end of the semester (after completing the 16 sessions). This activity was conducted in two days especially on Saturdays and Sundays and was generally used as the evaluation of the 16 activities along the semester. The specific objectives of this activity were:

a. to evaluate individual and group participation in one semester;

b. to give cognitive and affective reinforcement; and

c. to evaluate the program in one semester.

After the implementation of the program in one semester, a questionnaire was distributed to 20 students (out of the 45 total students) who were active and proactive during the program. The questionnaire aimed at measuring the students' response in terms of learning objectives, materials, activities, authenticity, evaluation, and motivation. The questionnaire had a four-point Likert scale 1 meaning 'not good', 2 'fair', 3 'good', and 4 'very good'. The responses from the questionnaire are presented in Table 2.

Table 2. The Results of Questionnaire after the Implementation

\begin{tabular}{|c|c|c|c|c|c|c|}
\hline \multirow[t]{2}{*}{ No } & \multirow[t]{2}{*}{ Aspects } & \multicolumn{4}{|c|}{ Assessment (\%) } & \multirow[t]{2}{*}{ Notes } \\
\hline & & 1 & 2 & 3 & 4 & \\
\hline 1. & The objective of the program is clear & 0 & 0 & 0 & 100 & \\
\hline 2. & The activities of the program are organized well & 0 & 0 & 85 & 15 & \\
\hline 3. & The materials are integrated and fun & 0 & 0 & 0 & 100 & \\
\hline 4. & The activities of the program are complete and easy to accomplish & 0 & 0 & 0 & 100 & \\
\hline 5 . & The games are authentic & 0 & 0 & 80 & 20 & \\
\hline 6. & The outdoor activities are inspiring & 0 & 0 & 0 & 100 & \\
\hline 7. & The indoor activities are motivating & 0 & 0 & 0 & 100 & \\
\hline 8. & The language used in the game are acceptable & 0 & 0 & 0 & 100 & \\
\hline 9. & The materials for realia are interesting & 0 & 0 & 85 & 15 & Some words still difficult \\
\hline 10. & The problem solution activities are useful & 0 & 0 & 0 & 100 & \\
\hline 11. & The one day English program is good evaluation & 0 & 0 & 85 & 15 & \\
\hline 12. & The English Camp is interesting and motivating & 0 & 0 & 85 & 15 & \\
\hline Total & & & & 35 & 65 & \\
\hline
\end{tabular}


Based on Table 2, all the 20 students were interested in joining the program in that the majority (13 students, about $65 \%$ ) highly agreed, and 7 students $(35 \%)$ agreed to the implementation of the program. This was similar with the result of other studies in different settings, such as those of Ahat (2013) and Allen (2010). The results also showed that the students experienced difficulties only in the activity related to realia. They found it difficult because the terms were related to specific words that were absolutely new for them. Moreover, most students thought that they were very motivating and inspiring to do, as also reported by Ajibade and Ndububa (2008) and Campbell and Storch (2011), in their studies motivation could boost the students' interest in joining all the outdoor learning activities. The importance of motivation in learning is crucial because as one of the dominant affective factors it is very determining to support students' cognitive development (Bernaus \& Gardner, 2008; Bernaus, Wilson, \& Gardner, 2009; Reza \& Hossein , 2013; Thamimi \& Shuib, 2009; Vivian \& Marek, 2010).

The curriculum promoted joyful learning to facilitate successful, confident, and responsible learning (QCDA, 2010). Using games in outdoor learning can be the best alternative to achieve these goals because of the competitive, controlled, and joyful nature of games that provide better learning-teaching activities (Sánchez, Morfín \& Campos, 2007). Games are full of ideas and simulations which train learners to develop their own capacities of learning (Perrotta, Featherstone, Aston, \& Houghton, 2013). The outdoor activities integrated five beneficial principles, including experience, pedagogy, integrating ideas, outdoor context, and learning (Dillon, Morris, O'Donnell, Reid, Rickinson, \& Scott, 2005).

Besides, outdoor activities definitely promote equal opportunities for students to have learning experiences (DCSF, 2007) and increase students' awareness and autonomy in learning English (Guo, 2011). These outside class learning activities also contribute significantly to change students' personality such as improved-social and emotional development (OFSTED, 2008). This is also higly consistent with Anwar (2015) in which motivation was created by providing interactive and fun activities for secondary students and adults. The interactive programs can be indoor and outdoor meaning that fun games and other constructivistic activities may increase not only students' affective aspects but also their cognitive ability.

The authenticity of the activities was also high as shown by the responses ( $80 \%$ or 16 students were interested and the remaining $20 \%$ (4 students) felt highly interested. In order to maximize the students' interest providing more varieties of activities was recommended.

\section{Conclusion}

Based on the implementation of the outdoor learning program through English Scout Organization, the conclusion of this study can be grouped into two areas, namely the interest of the program and the students' responses. The brief conclusive statement can be noted as follows:

1. The students are interested in English Scout Program because it is basically needed based on their needs. The outdoor learning program helps them a lot in learning outside the class. This allows more time allotment to study English freely compared with formal classes. This program further pursues students to have more interaction, physical activities, games, and problem solving. One Day Big English and English Camp are the two break periods for conducting evaluation especially of students' individual or group participation.

2. Students' responses after the implementation of the English Scout Program are satisfying; meaning, they are interested in joining the whole activities in the program.

This research has contributed a model of effective teaching for secondary students particularly on how to design and develop an outdoor English activity. The qualities that should be considered to develop beneficial programs for learners are interactivity and authenticity. These two influencing parameters are certainly able to maintain students' activeness in English learning classes.

\section{References}

Ahat, R. (2013). Motivation, gender, and learner performance of English as an L3 in the Xinjiang Uyghur autonomous region. English Language Teaching, 6(9), 158-167

Ajibade, Y., \& Ndububa, K. (2008). Effects of word games, culturally relevant songs, and stories on students' motivation in a Nigerian English language class. TESL Canada Journal, 25(2), 27-48

Allen, H. W. (2010). Language learning motivation during short-term study abroad: An activity theory perspective. Foreign Language Annals, 43(1), 27-49.

Anwar, K. (2000). Developing English Syllabus for Animal Husbandry School in Muhammadiyah University of Malang. Unpublished Thesis: Postgraduate Programme, State University of Malang.

Anwar, K. (2015). A Constructive Teaching Model in Learning Research Concept for English Language Teaching Students. International Education Studies, 8(5), 62-68, http://dx.doi.org/10.5539/ies.v8n5p62

Anwar, K. \& Husniah, R. (2016). Evaluating Integrated Task Based Activities and Computer Assisted Language Learning (CALL). English Language Teaching, 9(4), 119-127, http://dx.doi.org/10.5539/elt.v9n4p119 
Al-Tamimi, A., \& Shuib, M. (2009). Motivation and attitudes towards learning English: A study of petroleum engineering undergraduates at Hadhramout University of Sciences and Technology. GEMA: Online Journal of Language Studies, 9(2), 29-55.

Arifani, Y. (2016a). The Implementation of Team-Based Discovery Learning to Improve Students' Ability in Writing Research Proposal. International Education Studies. 9(2), 111-119, http://dx.doi.org/10.5539/ies.v9n2p111

Arifani, Y. (2016b). Optimizing EFL Learners' Sensitizing Reading Skill: Development of Local Content-Based Textbook. English Language Teaching. 9(5). 1-7, http://dx.doi.org/10.5539/elt.v9n5p1

Beames, S., Atencio, M. \& Ross, H. (2009) Taking excellence outdoors. Scottish Educational review, 41(2), 32-41

Bernaus, \& Gardner. (2008). Teacher Motivation Strategies, Student Perceptions, Student Motivation, and English Achievement. The Modern Language Journal, 92(iii).

Bernaus, Wilson, \& Gardner. (2009). Teachers' motivation, classroom strategy use, students' motivation and second language achievement. JPOOSRÉT AM LAINNUGEULA VRUEMZ 12, junio 2009. Retrieved from http://www.ugr.es

Campbell, E., \&Storch, N. (2011). The changing face of motivation: A study of second language learner' motivation over time. Australian Review of Applied Linguistics, 34(2), 166-192.

DCSF, (2007), Effective practice: outdoor learning, Nottingham, Department for Children, Schools and Families. Retrieved on 6 March 2012 at www.urbanforestschool.co.uk/PDF/3_3b_ep.pdf

Dillon, J, Morris, M, O’Donnell, L, Reid, A., Rickinson, M. \& Scott, W. (2005). Engaging and Learning with the Outdoors: The Final Report of the Outdoor Classroom in a Rural Context Action Research Project, Reading, NFER. Available at www.bath.ac.uk/cree/resources/OCR.pdf [accessed 6 March 2012]

Dornyei, Z. (2005). The Psychology of the Language Learner: Individual Differences in Second LanguageAcquisition. New Jersey: Lawrence Erlbaum Associates, Inc., Publishers

Gill, T, (2009). No Fear: Growing up in a risk-averse society, London, Calouste Gulbenkian Foundation.

Guo, S. (2011). Impact of an Out-of-class Activity on Students' English Awareness, Vocabulary, and Autonomy. Language Education in Asia, 2(2), 246-256. http://dx.doi.org/10.5746/LEiA/11/V2/I2/A07/Guo

McGriff, S.J. (2000). Instructional System Design (ISD) Using the ADDIE Model, retrieved from www.ehopac.org., on June 20, 2010.

OFSTED. (2008). Learning outside the classroom: how far should you go? Retrieved from www.ofsted.gov.uk/Ofstedhome/Publications-and-research/Browse-all-by/Documents-by-type/Thematic-reports/Learning-outside-the-classroom

Patton, M. Q. (2002). Qualitative Research and Evaluation Methods. London: Sage Publications.

Perrotta, C., Featherstone, G., Aston, H., \& Houghton, E. (2013). Game-based Learning: Latest Evidence and Future Directions (NFER Research Programme: Innovation in Education). Slough: NFER.

Porritt, J., Hopkins, D., Birney A., \& Reed, J. (2009). Every child's future: leading the way, Nottingham, National College.

Pound, L, (2005). How Children Learn: From Montessori to Vygotsky: Educational Theories and Approaches Made Easy, London, Step Forward Publishing Ltd

QCDA. (2010). The aims of the curriculum. Retrieved from http://curriculum.qcda.gov.uk/uploads/Curriculum\%20aims_tcm8-15741.pdf

Reza, M., \& Hossein. (2013). The Role of EFL Teachers in Increasing High School Students' Motivation in Classroom. International Journal of Education and Research, 1(10).

Sánchez M., M., M., Morfín A., P., \& Campos V., E., P. (2007). Interactive games in the teaching-learning process of a foreing language. Teoría y Praxis 4, 47-66.

Scott, W. \& Gough, S. (2003).Sustainable Development and Learning: Framingthe Issues. London: RoutledgeFalmer.

Sugiyono. 2011. Metode Penelitian Kuatitatif, Kualitatif, dan R\&D. Bandung: Alfabeta.

Vivian, W. U., \& Marek. (2010). Making English a "Habit": Increasing Confidence, Motivation. TOJET: The Turkish Online Journal of Educational Technology, 9(4).

Wollmann, H. (2003), Evaluation in Public-Sector Reform. Towards a third wave of evaluation, In H. Wollmann ed., Evaluation in Public-Sector Reform, (pp. 1-11), Cheltenham: Edward Elgar.

You, C. \& Dornyei, Z. (2014). Language Learning Motivation in China: Results of a Large-Scale Stratified Survey. Applied Linguistics.doi:10.1093/applin/amu046

Zulganef. (2006). Pemodelan Persamaan Struktur dan Aplikasinya menggunakan AMOS 5. Bandung: Pustaka. 
Appendix A. Internal reliability results

Item-Total Statistics

\begin{tabular}{lrrrr}
\hline & $\begin{array}{c}\text { Scale Mean if Item } \\
\text { Deleted }\end{array}$ & $\begin{array}{c}\text { Scale Variance if } \\
\text { Item Deleted }\end{array}$ & $\begin{array}{c}\text { Corrected Item-Total } \\
\text { Correlation }\end{array}$ & $\begin{array}{c}\text { Cronbach's Alpha if } \\
\text { Item Deleted }\end{array}$ \\
\hline VAR00001 & 39.9231 & 24.744 & .922 & .967 \\
VAR00002 & 39.9231 & 26.577 & .831 & .969 \\
VAR00003 & 39.9231 & 26.577 & .831 & .969 \\
VAR00004 & 40.1538 & 26.308 & .817 & .970 \\
VAR00005 & 39.9231 & 24.744 & .922 & .967 \\
VAR00006 & 39.9231 & 26.577 & .831 & .969 \\
VAR00007 & 39.9231 & 26.577 & .831 & .969 \\
VAR00008 & 40.1538 & 26.308 & .817 & .970 \\
VAR00009 & 39.9231 & 24.744 & .922 & .967 \\
VAR00010 & 39.9231 & 26.577 & .831 & .969 \\
VAR00011 & 39.9231 & 26.577 & .831 & .969 \\
VAR00012 & 40.1538 & 26.308 & .817 & .970 \\
\hline
\end{tabular}

\section{Appendix B. A Prototype of the Results in Needs Analysis}

\begin{tabular}{ll}
\hline Audience & \\
\hline $\begin{array}{l}\text { The level of the students' ability in English } \\
\text { Interest }\end{array}$ & $\begin{array}{l}\text { Post Elementary } \\
\text { Medium } \\
\text { Motivation }\end{array}$ \\
& Medium \\
\hline AIMS & \\
\hline Skills of English & Speaking (dominant) \\
Integrated skills & Reading, writing, and listening (additional) \\
& Combination between playing and learning language
\end{tabular}

\begin{tabular}{l}
\hline Content \\
\hline Language descriptions \\
\hline Structural \\
Functional
\end{tabular}

Combinations

Combination between functional and structural

\begin{tabular}{l} 
Language Points \\
\hline Particular Structures
\end{tabular}

Verb be, present tense, and other simple tenses, simple sentences for reports, other generals structures used in basic communication

Vocabulary areas

Vocabularies related to daily life, school environment, food and drink, description of things and places, etc.

\section{Content organization}

Language points

Subject matters content

Subject matters

Language points

Combinations of means

Easier to more difficult content

Easier to more difficult

Guided to free

\begin{tabular}{ll}
\hline Methodology & \\
\hline Kinds of Exercises & Guided - free \\
\hline Guided - free & Comprehension - production \\
Comprehension - production & Subjective answers \\
Objective answers & Problem solving \\
Subjective answers & Role-play, simulations, drama, games \\
Problem solving & \\
Role-play, simulations, drama, games & \\
Some other kind? & \\
& \\
\hline Learning Techniques & Pair work \\
\hline Pair work & Small group work \\
Small group work
\end{tabular}


Student presentation

Technical subject-matter

Others
Student presentation

Interactive games

Ceremony (formal and non-formal ceremony)

Writing reports

Information gap activities

Joyful learning

Interactive problem solving

\begin{tabular}{ll}
\hline Aids & \\
\hline Tape- Recorders & Video \\
Realia & Fruits and vegetables \\
Loud Speaker & Outdoor activities \\
\hline
\end{tabular}

\section{Appendix C. The Scope of Material and Strategy}

\begin{tabular}{|c|c|c|}
\hline Material & Strategy & Target \\
\hline \multicolumn{3}{|c|}{$\begin{array}{l}\text { Practices to have ceremony (opening } \\
\text { and closing) }\end{array}$} \\
\hline Find things at school environment & $\begin{array}{l}\text { Matching and Collecting words (form a } \\
\text { group to implement this activity and } \\
\text { make a report) }\end{array}$ & $\begin{array}{l}\text { Students are able to mention and } \\
\text { memorize all words at school } \\
\text { environment) }\end{array}$ \\
\hline Greetings & $\begin{array}{l}\text { Drilling and presenting (each group is } \\
\text { given the text and they have to practice } \\
\text { with other group) }\end{array}$ & $\begin{array}{l}\text { Students are simply able to use greeting } \\
\text { in daily life. }\end{array}$ \\
\hline Counting $1-50$ & $\begin{array}{l}\text { Simple Jigsaw (each group is given } \\
\text { things and they have to mention as a } \\
\text { game) }\end{array}$ & Students are able to count $1-50$ \\
\hline Introducing self and others & $\begin{array}{l}\text { Drilling (each person introduce } \\
\text { her/himself at different group) }\end{array}$ & $\begin{array}{l}\text { Students are able to introduce } \\
\text { individually }\end{array}$ \\
\hline Vegetable & $\begin{array}{l}\text { Interactive Jigsaw Game (each group } \\
\text { mention and present all vegetables they } \\
\text { have got from shopping) }\end{array}$ & $\begin{array}{l}\text { Students are able to mention and } \\
\text { memorize vegetables. }\end{array}$ \\
\hline Kings of things and rooms & $\begin{array}{l}\text { Group Work Activities(group should } \\
\text { stick the things they have and present } \\
\text { them to other groups) }\end{array}$ & $\begin{array}{l}\text { Students are able to mention all things } \\
\text { in each room. }\end{array}$ \\
\hline Family & Games (playing a family tree in group). & $\begin{array}{l}\text { Students are able to understand } \\
\text { members of family. }\end{array}$ \\
\hline Time & $\begin{array}{l}\text { Drilling and Discussing (each group is } \\
\text { given a picture of time and present it to } \\
\text { other group) }\end{array}$ & Students are familiar about time. \\
\hline Our body & $\begin{array}{l}\text { Drilling and Presenting (sing a song and } \\
\text { movement) }\end{array}$ & $\begin{array}{l}\text { Students can mention part of body } \\
\text { correctly. }\end{array}$ \\
\hline Foods & $\begin{array}{l}\text { Drilling and Discussing (chaining game } \\
\text { about food) }\end{array}$ & $\begin{array}{l}\text { Students are able to mention kinds of } \\
\text { foods.. }\end{array}$ \\
\hline Fruits & $\begin{array}{l}\text { Drilling and Presenting (song and } \\
\text { movement game) }\end{array}$ & Students are familiar about fruits \\
\hline Occupation & Games (pictures of professions) & $\begin{array}{l}\text { Students are able to mention the kinds } \\
\text { of profession correctly. }\end{array}$ \\
\hline Descriptive Text & $\begin{array}{l}\text { Drilling and Jigsaw (share and discuss } \\
\text { about descriptive text) }\end{array}$ & $\begin{array}{l}\text { Students are familiar about descriptive } \\
\text { text. }\end{array}$ \\
\hline $\begin{array}{l}\text { Daily activities } \\
\text { (Simple present) }\end{array}$ & $\begin{array}{l}\text { Drilling and Interactive games (each } \\
\text { group stick varieties of sentences, and } \\
\text { they have to suit the sentences and the } \\
\text { pictures, then present them to other } \\
\text { groups) }\end{array}$ & $\begin{array}{l}\text { Students can communicate using simple } \\
\text { words for everyday life. }\end{array}$ \\
\hline
\end{tabular}

